\title{
$R$-Flurbiprofen Traps Prostaglandins within Cells by Inhibition of Multidrug Resistance-Associated Protein-4
}

\author{
Ivonne Wobst ${ }^{1}$, Lisa Ebert ${ }^{2}$, Kerstin Birod ${ }^{1}$, Marthe-Susanna Wegner ${ }^{1}$, Marika Hoffmann ${ }^{3,+}$, \\ Dominique Thomas ${ }^{1}$, Carlo Angioni ${ }^{1}$, Michael J. Parnham ${ }^{2}$, Dieter Steinhilber ${ }^{3}$, \\ Irmgard Tegeder $^{1}$, Gerd Geisslinger ${ }^{1,2}$ and Sabine Grösch ${ }^{1, *}$ \\ 1 Pharmazentrum frankfurt, ZAFES, Institute for Clinical Pharmacology, Goethe-University Frankfurt, \\ Theodor-Stern-Kai 7, 60590 Frankfurt/Main, Germany; mail@iwobst.de (I.W.); \\ k.birod@med.uni-frankfurt.de (K.B.); marthewegner@me.com (M.-S.W.); \\ thomas@med.uni-frankfurt.de (D.T.); Angioni@em.uni-frankfurt.de (C.A.); \\ tegeder@em.uni-frankfurt.de (I.T.); geisslinger@em.uni-frankfurt.de (G.G.) \\ 2 Fraunhofer Institute for Molecular Biology and Applied Ecology IME, Project Group Translational \\ Medicine and Pharmacology TMP, Theodor-Stern-Kai 7, 60590 Frankfurt am Main, Germany; \\ ebert.lisa@web.de (L.E.); Michael.Parnham@ime.fraunhofer.de (M.J.P.) \\ 3 Institute of Pharmaceutical Chemistry, ZAFES, Johann Wolfgang Goethe-University Frankfurt, \\ Max-von-Laue-Str. 9, D-60438 Frankfurt, Germany; steinhilber@em.uni-frankfurt.de \\ * Correspondence: groesch@em.uni-frankfurt.de; Tel.: +49/69-6301-7820; Fax: +49/69-6301-7636 \\ + Marika Hoffmann was a co-worker at the Institute of Pharmaceutical Chemistry. She is sadly passed away.
}

Academic Editor: Johannes Haybaeck

Received: 23 November 2016; Accepted: 23 December 2016; Published: 30 December 2016

\begin{abstract}
R-flurbiprofen is the non-COX-inhibiting enantiomer of flurbiprofen and is not converted to $S$-flurbiprofen in human cells. Nevertheless, it reduces extracellular prostaglandin $\mathrm{E}_{2}\left(\mathrm{PGE}_{2}\right)$ in cancer or immune cell cultures and human extracellular fluid. Here, we show that $R$-flurbiprofen acts through a dual mechanism: (i) it inhibits the translocation of $\mathrm{cPLA}_{2 \alpha}$ to the plasma membrane and thereby curtails the availability of arachidonic acid and (ii) $R$-flurbiprofen traps $\mathrm{PGE}_{2}$ inside of the cells by inhibiting multidrug resistance-associated protein 4 (MRP4, ABCC4), which acts as an outward transporter for prostaglandins. Consequently, the effects of $R$-flurbiprofen were mimicked by RNAi-mediated knockdown of MRP4. Our data show a novel mechanism by which $R$-flurbiprofen reduces extracellular PGs at physiological concentrations, particularly in cancers with high levels of MRP4, but the mechanism may also contribute to its anti-inflammatory and immune-modulating properties and suggests that it reduces PGs in a site- and context-dependent manner.
\end{abstract}

Keywords: flurbiprofen; MRP4; cPLA $2 ; \mathrm{PGE}_{2}$

\section{Introduction}

Prostaglandins (PGs) are key mediators in the regulation of pain and inflammation, mucosal health, tumor growth, angiogenesis, blood pressure, kidney function, ocular pressure, neurovascular coupling, and glial and neuronal functions [1]. They are produced in a multi-step process involving cytosolic phospholipase $\mathrm{A}_{2}\left(\mathrm{cPLA}_{2}\right)$, cyclooxygenase-1 or $-2(\mathrm{COX}-1 /-2)$ and subsequent prostaglandin synthases. PGs poorly pass membranes and therefore use cell membrane-bound transporters for cellular release. An important membrane transporter for the export of PGs from cells to the extracellular space is the multidrug resistance protein 4 (MRP4), also known as ATP-binding cassette transporter (ABCC4). Once released, PGs bind to and activate specific PG receptors in an autocrine or paracrine manner. 
PGs play a distinct role in many pathophysiological processes such as pain, inflammation, cancer and autoimmunity. Pharmacologically, PG release is commonly inhibited by blocking COX-1 and/or COX-2 with non-steroidal anti-inflammatory drugs (NSAIDs), such as flurbiprofen. Flurbiprofen has been used to treat patients with rheumatoid arthritis for more than 40 years [2]. It belongs to the class of 2-arylpropionic acids and is the 1:1 racemate of the $S$ - and $R$-enantiomers. $S$-flurbiprofen inhibits COX-1 and -2, but $R$-flurbiprofen is inactive as a COX-inhibitor. Nevertheless, both enantiomers have anti-nociceptive, anti-inflammatory and anti-cancer effects [3-6]. $R$-flurbiprofen is not inverted to $S$-flurbiprofen in humans and minimally in rats $[5,7]$. Hence, effects observed in humans or rats or human cells cannot be attributed to COX inhibition.

About 30 years ago flurbiprofen was found to reduce the risk of colon cancer, which was ascribed mainly to its inhibitory effect on COX [8,9]. In further studies, we demonstrated that the anti-proliferative effects of both $R$ - and $S$-flurbiprofen in colon cancer cells were mediated at least in part via COX-independent mechanisms $[3,10]$. $R$ - and $S$-flurbiprofen regulate signaling pathways converging on c-Jun N-terminal kinase (JNK) [3], nuclear factor kappa B (NF-kB) [4] or p53 [10]. Other NSAIDS also reduce the risk of colon cancer, but are not used as "anti-cancer drugs" because they cause gastrointestinal and cardiovascular side effects, mainly caused by inhibition of COX-1- and COX-2-mediated generation of prostacyclin, and $\mathrm{PGE}_{2}$, respectively [11-13]. Hence, $R$-flurbiprofen has some advantages. $R$-flurbiprofen inhibited the organ release of prostaglandins ex vivo, e.g., from the lung and brain of the rat, but not in the mucosa of the small intestine at concentrations of $25 \mathrm{mg} / \mathrm{kg}$ [14,15]. $R$-flurbiprofen also reduced PG levels in blister fluid [16] and the microdialysates of the rat brain or spinal cord [14]. Hence, it obviously reduces extracellular prostaglandin levels without affecting COXs. In the present study, we assessed the underlying molecular mechanisms using an in vitro model of human cancer cell lines, with differential expression of MRP4, based on the hypothesis that $R$-flurbiprofen, which has been shown to interfere with organic anion transporters (OATs), may target MRP4-mediated PG transport.

\section{Results}

\subsection{R-Flurbiprofen Reduces Prostaglandin Levels}

Several studies have shown that $R$-flurbiprofen inhibits PG levels in different tissues, despite its lack of COX-inhibiting activity. We confirmed these effects in cancer cell supernatants of human cervical (HeLa), lung (A-549) and colon (HCA-7) cancer cell lines. HeLa and A-549 cells produce only marginal basal amounts of $\mathrm{PGE}_{2}(17.4 \pm 2.2 \mathrm{pg} / \mathrm{mL}(\mathrm{HeLa})$ and $231 \pm 73 \mathrm{pg} / \mathrm{mL}$ (A549)). Therefore, these cells were stimulated with IL-1 $\beta$ (A-549) or IL-1 $\beta+\mathrm{TNF} \alpha$ (HeLa) for $16 \mathrm{~h}$, resulting in a strong increase of $\mathrm{PGE}_{2}$ in these cells $(5807 \pm 110 \mathrm{pg} / \mathrm{mL}$ (A-549), $4617 \pm 537 \mathrm{pg} / \mathrm{mL}$ (HeLa)). HCA-7 cells produce high amounts of $\mathrm{PGE}_{2}$ without stimulation $(6812 \pm 1284 \mathrm{pg} / \mathrm{mL}) \cdot R$-flurbiprofen reduced $\mathrm{PGE}_{2}$ concentrations in supernatants of all three cell lines with $\mathrm{IC}_{50}$ values of $5.1 \mu \mathrm{M}(\mathrm{HeLa})$, $5.6 \mu \mathrm{M}$ (A-549) and $11.7 \mu \mathrm{M}$ (HCA-7), respectively (Figure 1A). $\mathrm{PGD}_{2}$ and $\mathrm{PGF}_{2 \alpha}$ were also reduced in the supernatants of all three cell lines after $R$-flurbiprofen treatment (Figure 1B), suggesting that $R$-flurbiprofen unspecifically affects all PGs. As expected, $S$-flurbiprofen, which is a potent COX-1/2 inhibitor, was more potent with an $\mathrm{IC}_{50}$ of $0.1 \mu \mathrm{M}$ (Figure $1 \mathrm{C}$ ). The effects of $R$-flurbiprofen are still clinically relevant because patients received up to $800 \mathrm{mg}$ (twice a day) [17], leading to plasma concentrations of about $185 \mu \mathrm{M}$ [18]. 
A

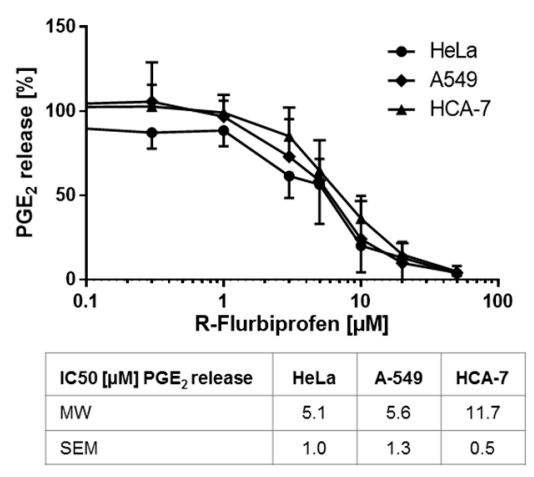

C

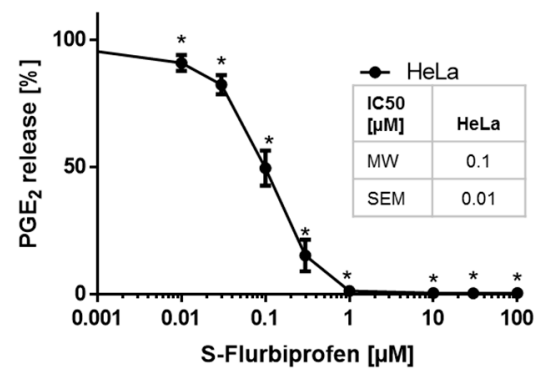

B
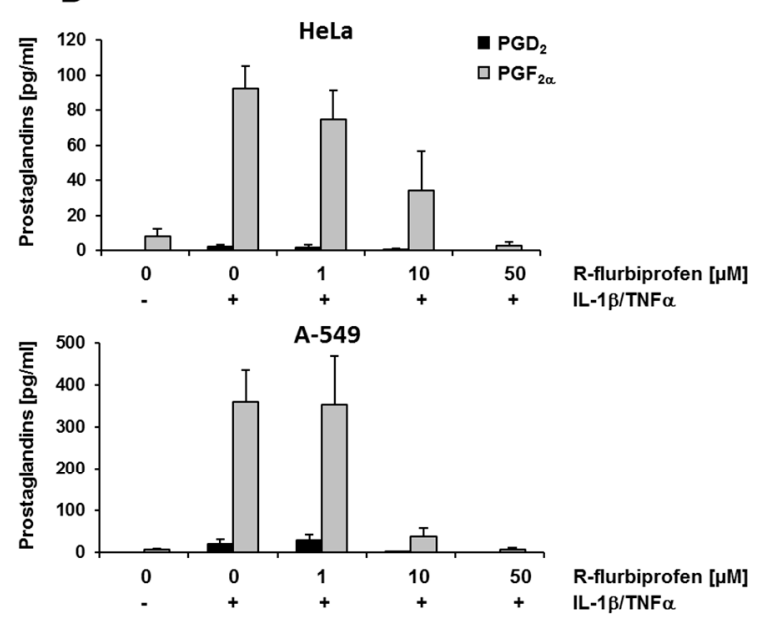

HCA-7

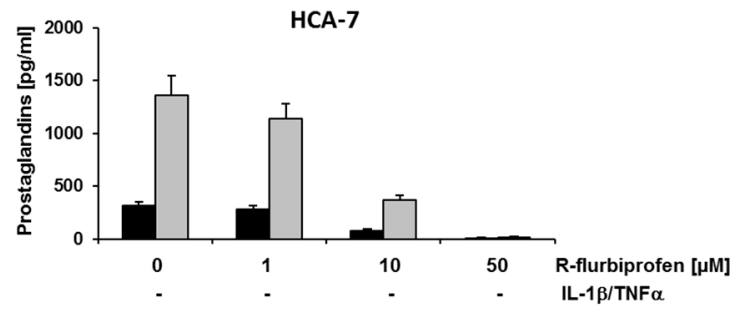

Figure 1. $\mathrm{PGE}_{2}$ in cell supernatant of human cancer cell lines: Cells were treated either with $0.1 \% \mathrm{DMSO}$ (control), S-flurbiprofen $(0.01-10 \mu \mathrm{M})$ or $R$-flurbiprofen $(0.03-50 \mu \mathrm{M})$ and, simultaneously, with IL-1 $\beta$ $(2 \mathrm{ng} / \mathrm{mL})$ for stimulation of A-549 cells or IL-1 $\beta(1 \mathrm{ng} / \mathrm{mL})+\mathrm{TNF} \alpha(5 \mathrm{ng} / \mathrm{mL})$ for stimulation of HeLa cells. HCA-7 cells were pre-incubated with medium containing either DMSO $(0.1 \%)$ or flurbiprofen for $1 \mathrm{~h}$ and this medium was replaced with fresh medium and the same additions. (A) $R$-flurbiprofen inhibited $\mathrm{PGE}_{2}$ production by all three cell lines at concentrations between 1 and $50 \mu \mathrm{M}$. Means \pm S.E.M. of four independent experiments; (B) $R$-flurbiprofen also inhibited the release of $\mathrm{PGD}_{2}$ and $\mathrm{PGF}_{2 \alpha}$ from HeLa, A-549 and HCA-7 cells in a concentration-dependent manner. Means \pm S.E.M. of three independent experiments; (C) $S$-flurbiprofen is 50-fold more potent than $R$-flurbiprofen in inhibiting $\mathrm{PGE}_{2}$ production in HeLa cells with an $\mathrm{IC}_{50}$ of about $100 \mathrm{nM}$. Means \pm S.E.M. of three independent experiments. Significant $p$ values are shown as: ${ }^{*} p \leq 0.05$.

\subsection{Inhibition of PG Release Is Not Mediated through COX-1/2- or mPGES-1}

We assessed the effect of $R$-flurbiprofen on the activity of purified COX-1, COX-2 and mPGES enzymes on COX-1 and COX-2 in the whole-blood assay and on protein expression in HeLa cells. $R$-flurbiprofen achieved a maximum inhibition of purified COX-1 and COX-2 of 30\% at $500 \mu \mathrm{M}$ (Figure 2A). The positive controls SC-560 (COX-1) [19] and celecoxib (COX-2) were much more potent. In contrast, in the whole-blood assay, $R$-flurbiprofen inhibited the release of thromboxane $\mathrm{B}_{2}$ (readout for COX-1 inhibition) as well as $\mathrm{PGE}_{2}$ (readout for COX-2 inhibition) with an $\mathrm{IC}_{50}$ (COX inhibition) of 130 and $246 \mu \mathrm{M}$, respectively (Figure 2B). The activity of purified mPGES-1 was inhibited by $R$-flurbiprofen with an $\mathrm{IC}_{50}$ of $369 \mu \mathrm{M}$ (Figure 2C), i.e., at much higher concentrations than PG inhibition in cell culture supernatants. Treatment with $R$-flurbiprofen had no effect on COX-1, COX-2, mPGES-1 or mPGES-2 protein expression, up to a concentration of $300 \mu \mathrm{M}$ (Figure 2D). $R$-flurbiprofen did not affect cPGES protein levels (data not shown). 


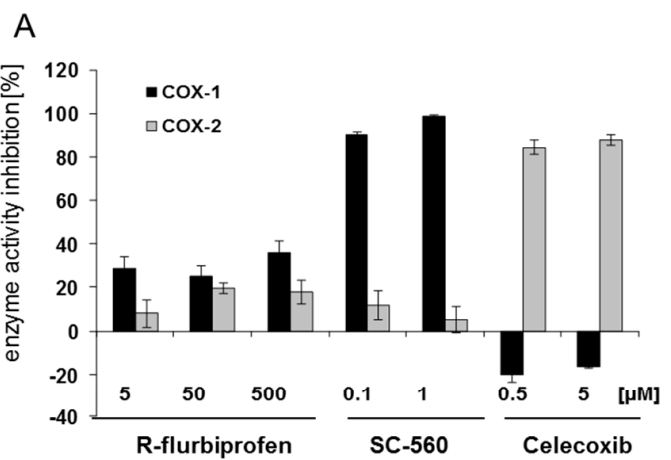

$\mathrm{B}$
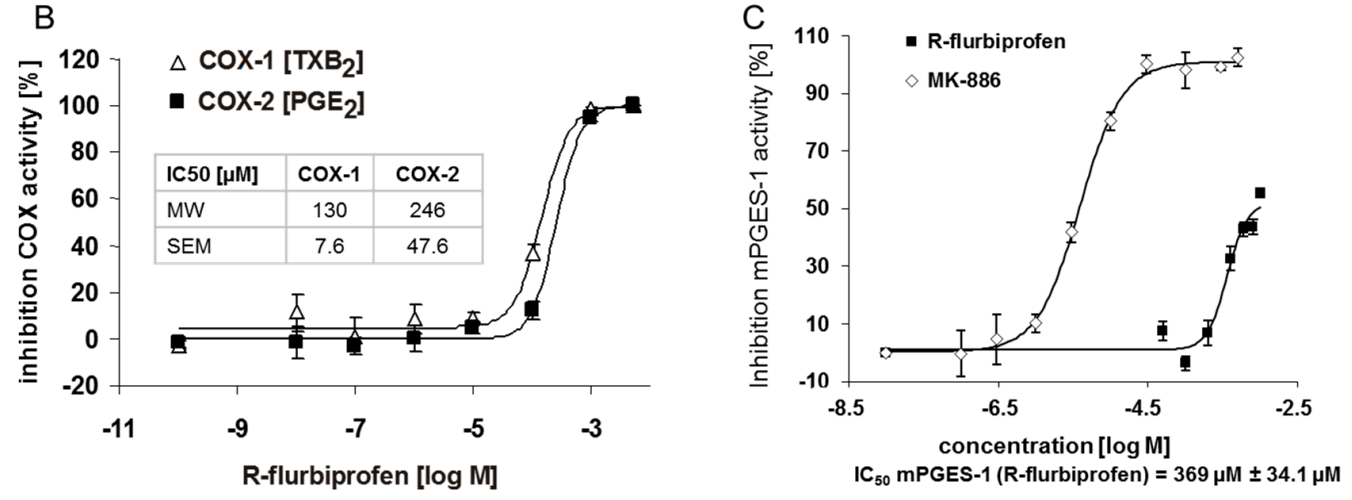

D

R-flurbiprofen $[\mu \mathrm{M}]$
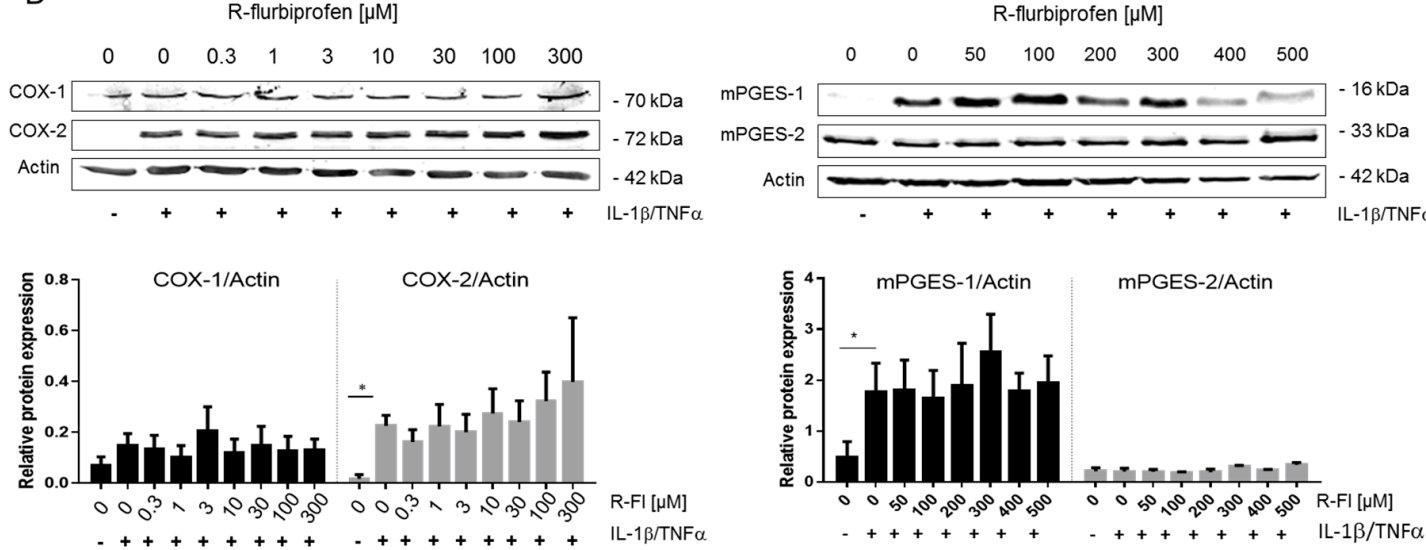

Figure 2. (A) COX inhibitor screening assay: in vitro inhibition of purified COX-1 and COX-2 protein by $R$-flurbiprofen, SC-560, and celecoxib. $R$-flurbiprofen inhibited COX-1 and COX-2 activity only marginally, without concentration dependency. Means \pm S.E.M. of four independent experiments; (B) Human whole-blood assay in vitro: human blood was pre-incubated with $R$-flurbiprofen or vehicle (DMSO) and subsequently stimulated either with $\mathrm{Ca}^{2+}$-ionophore $(20 \mu \mathrm{M}$ A23187) for induction of COX-1 activity, resulting in the formation of thromboxane $\mathrm{B}_{2}\left(\mathrm{TXB}_{2}\right)$, or with LPS $(5 \mathrm{mg} / \mathrm{mL})$ for induction of COX-2 activity, resulting in the formation of $\mathrm{PGE}_{2}$. $\mathrm{IC}_{50}$ values were calculated using a sigmoid Emax model. Data presented are means \pm S.E.M. of four independent experiments; (C) mPGES-1 activity assay: mPGES-1 activity was measured in the microsomal fraction of HeLa cells in vitro. $R$-flurbiprofen only marginally affected mPGES- 1 activity, with an $\mathrm{IC}_{50}$ of about $370 \mu \mathrm{M}$. In contrast, MK-886 inhibited mPGES- 1 activity with an $\mathrm{IC}_{50}$ of $4 \mu \mathrm{M}$. $\mathrm{IC}_{50}$ values were calculated using a sigmoid Emax model. Data presented are means \pm S.E.M. of four independent experiments; (D) Western blot analysis of COX-1 and COX-2 (whole cell lysate) and mPGES-1/2 (microsomal fraction). One representative experiment out of three is shown, as well as the quantification of three Western blots. Data presented are means \pm S.E.M. of three independent experiments; statistical analysis was done with one-way ANOVA. Significant $p$ values are shown as: ${ }^{*} p \leq 0.05$. 


\subsection{R-Flurbiprofen Targets Alternative Candidates in the PG Pathway}

The results presented above did not explain the $R$-flurbiprofen-mediated reduction of PGs in cell culture supernatants. We therefore assessed alternative targets. PG production starts with the release of arachidonic acid from phospholipids in cell membranes. The most important enzyme responsible for the release of arachidonic acid (AA) from phospholipids is the cytoplasmic phospholipase $\mathrm{A}_{2 \alpha}\left(\mathrm{cPLA}_{2 \alpha}\right)$ [20]. $R$-flurbiprofen inhibited the activity of purified recombinant cPLA $2 \alpha$ at high concentrations with an $\mathrm{IC}_{50}$ of $202 \mu \mathrm{M}$ (Figure 3A). We also assessed cPLA $2 \alpha$ activity in cell culture indirectly by measuring $\mathrm{PGE}_{2}$ formation after arachidonic acid (AA) addition $(20 \mu \mathrm{M})$ to the cells to uncouple $\mathrm{PGE}_{2}$ production from endogenous AA release. For this assay, we used stimulated HeLa cells and incubated them with celecoxib, SC-560, cPLA $2 \alpha$ inhibitor and different concentrations of $R$-flurbiprofen (Figure 3B). AA prevented the inhibition of $\mathrm{PGE}_{2}$ release by the $\mathrm{PLA}_{2 \alpha}$ inhibitor but the addition of AA failed to prevent the inhibition of $\mathrm{PGE}_{2}$ release after celecoxib or SC-560 treatment, as expected. However, AA abolished the effects of $10 \mu \mathrm{M} R$-flurbiprofen, but could only in part reverse the effect at higher $R$-flurbiprofen concentrations of 20 and $50 \mu \mathrm{M}$. Hence, the effects of $R$-flurbiprofen depended in part on the release of AA from phospholipids by $\mathrm{cPLA}_{2 \alpha}$ in intact cells, but not in cell-free assays, suggesting that $R$-flurbiprofen did not affect the catalytic activity of $c P L A_{2 \alpha}$ but rather its targeting to the plasma membrane.
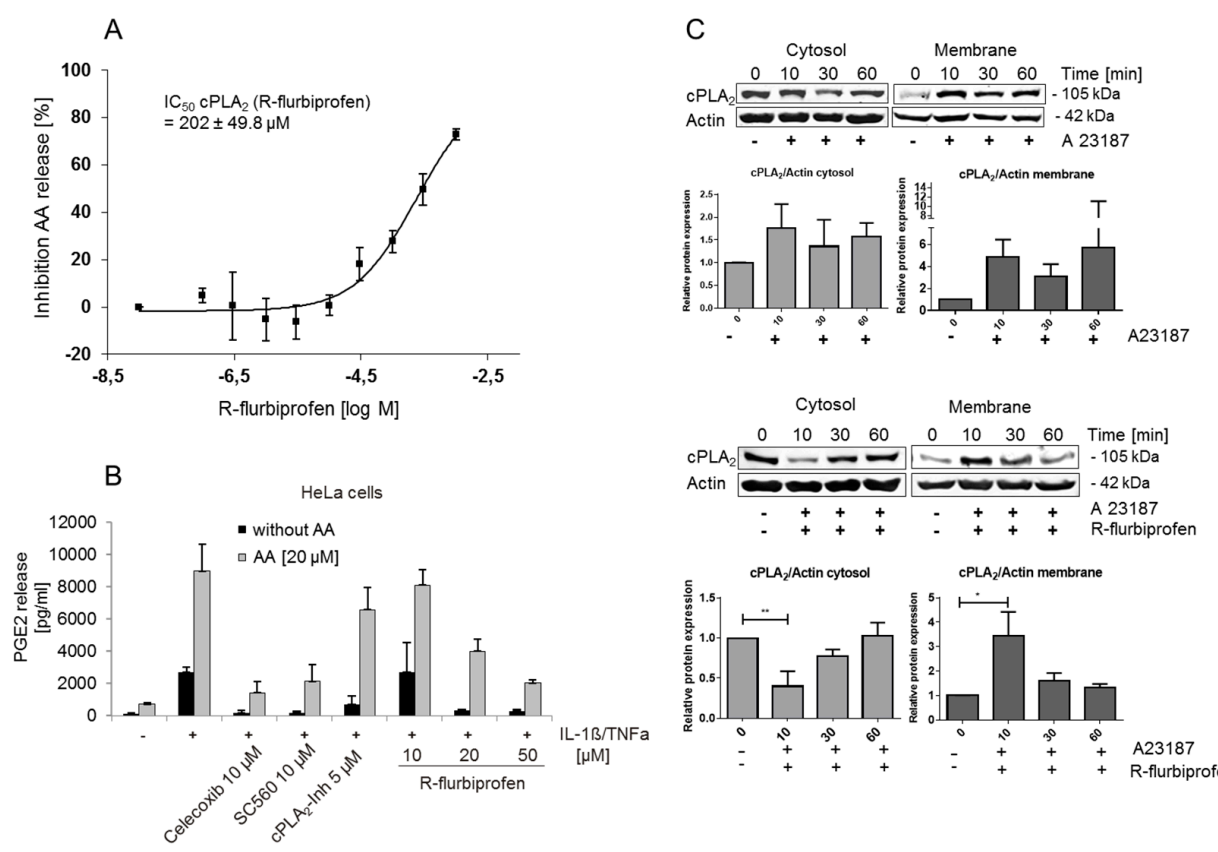

Figure 3. (A) $\mathrm{cPLA}_{2 \alpha}$ activity assay: for the in vitro $\mathrm{CPLA}_{2 \alpha}$ activity assay, small unilamellar vesicles containing 1-palmitoyl-2 arachidonyl-sn-glycero-3-phosphocholine (PAPC) and 1-palmitoyl-2-oleoyl-snglycerol (POG) 2:1 were prepared and incubated with cPLA $2 \alpha$ enzyme isolated from Sf9-insekt cells. The $\mathrm{IC}_{50}$ value was calculated using a sigmoid Emax model. Data presented are means \pm S.E.M. of four independent experiments; (B) $\mathrm{PGE}_{2}$ in cell supernatant of HeLa cells with or without arachidonic acid addition: HeLa cells were stimulated with IL-1 $\beta(1 \mathrm{ng} / \mathrm{mL})$ and TNF $\alpha(5 \mathrm{ng} / \mathrm{mL})$ and simultaneously treated with $R$-flurbiprofen (10, 20, $50 \mu \mathrm{M}), 10 \mu \mathrm{M}$ celecoxib, $10 \mu \mathrm{M}$ SC-560 or $5 \mu \mathrm{M}$ cPLA ${ }_{2 \alpha}$ inhibitor. Additionally, $20 \mu \mathrm{M}$ arachidonic acid (AA) was added to the cells, and after $16 \mathrm{~h}$ incubation, the $\mathrm{PGE}_{2}$ level in supernatants was determined. Means \pm S.E.M. of three independent experiments; (C) Western blot analysis of cPLA ${ }_{2 \alpha}$ in A549 cytosolic and membrane fractions: A549 cells were stimulated with the $\mathrm{Ca}^{2+}$-ionophore (A23187) for 10, 30 or $60 \mathrm{~min}$ and additionally treated with $100 \mu \mathrm{M} R$-flurbiprofen. Actin was used as a loading control. One representative experiment out of three is shown, as well as the quantification of the three Western blots. Data presented are means \pm S.E.M. of three independent experiments; statistical analysis was done with one-way ANOVA. Significant $p$ values are shown as: ${ }^{* *} p \leq 0.01,{ }^{*} p \leq 0.05$. 
$R$-flurbiprofen did not affect the total $\mathrm{CPLA}_{2 \alpha}$ protein expression as assessed by Western blot analysis (data not shown), but inversely regulated the expression in cytoplasmic and membrane compartments. $\mathrm{CPLA}_{2 \alpha}$ translocation from the cytosol to membranes is increased by intracellular concentrations of calcium $\left[\mathrm{Ca}^{2+}\right]_{\mathrm{i}} \cdot \mathrm{Ca}^{2+}$ binds to the N-terminal C2 domain of $\mathrm{CPLA}_{2 \alpha}$ which is a calcium and phospholipid binding domain that functions primarily to promote interactions with membranes [21]. We used A549 cells for this experiment because baseline membrane targeting of $\mathrm{CPLA}_{2 \alpha}$ is low in these cells. They were stimulated with calcium-ionophore A23178 with/without $R$-flurbiprofen (Figure 3C). A23178 resulted in a translocation of cPLA $2 \alpha$ from the cytosol to cell membranes, which was temporally inhibited by $R$-flurbiprofen. Hence, $R$-flurbiprofen inhibited $\mathrm{cPLA}_{2 \alpha}$ activity in a cellular context by blocking its $\mathrm{Ca}^{2+}$-induced translocation to cell membranes. These effects, however, accounted only for a part of the $R$-flurbiprofen-mediated PG inhibition, as Figure 3B indicates; therefore, other additional mechanisms contribute to PG inhibition.

\subsection{R-Flurbiprofen Traps PGs Inside of Cells}

PGs are poorly membrane permeable and are transported via specific membrane proteins. The export from cells is mainly mediated by the multidrug resistance-associated protein 4 (MRP4) [22] whereas the reimport is dependent on the prostaglandin transporter (PGT) $[23,24]$.

A

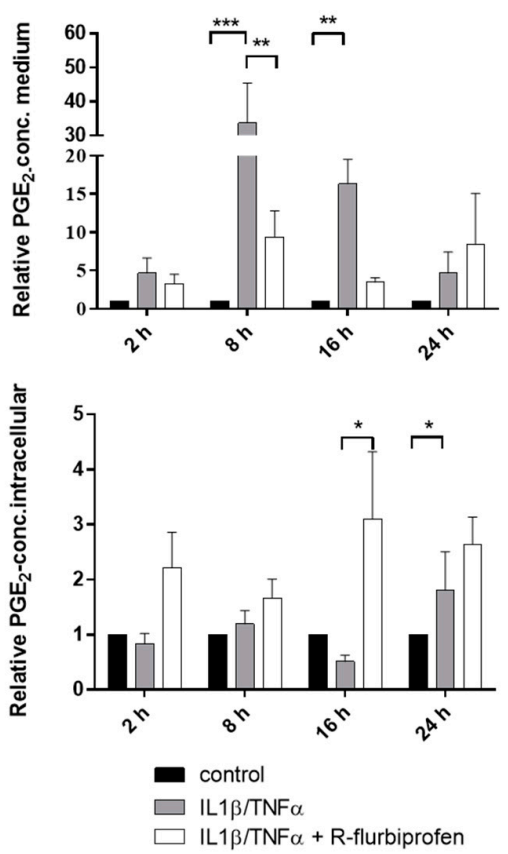

B
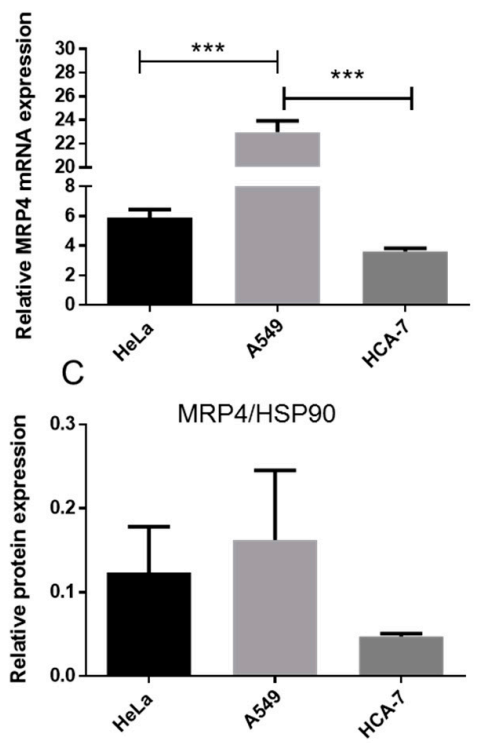

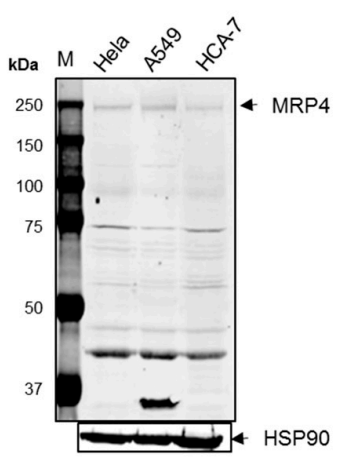

Figure 4. (A) Extracellular and intracellular $\mathrm{PGE}_{2}$ concentrations of stimulated HeLa cells: HeLa cells were stimulated with IL-1 $\beta(1 \mathrm{ng} / \mathrm{mL})$ and $\mathrm{TNF} \alpha(5 \mathrm{ng} / \mathrm{mL})$ for $16 \mathrm{~h}$ and additionally treated with $10 \mu \mathrm{M} R$-flurbiprofen. $\mathrm{PGE}_{2}$ in the supernatant and in full cell lysate was determined by nano-LC-MS/MS. Means \pm S.E.M. of four independent experiments; (B) mRNA expression of MRP4 in unstimulated cancer cells: mRNA from untreated HeLa, A549, and HCA-7 cells was prepared and MRP4 expression detected by quantitative RT-PCR. Means \pm S.E.M. of three independent experiments, statistical analysis was done with one-way ANOVA; (C) Western blot analysis of MRP4 in unstimulated cancer cells: protein extracts from untreated HeLa, A549, and HCA-7 cells were prepared, separated by SDS-PAGE and electro-blotted onto a nitrocellulose membrane. MRP4 expression was detected by an anti-MRP4-antibody. HSP90 was used as the loading control. One representative experiment out of three is shown as well as the quantification of the three Western blots. Data presented are means \pm S.E.M. of three independent experiments; statistical analysis was done with one-way ANOVA. Significant $p$ values are shown as: ${ }^{* * *} p \leq 0.001,{ }^{* *} p \leq 0.01,{ }^{*} p \leq 0.05$. 
To investigate whether $R$-flurbiprofen inhibits PG release, we measured intra- and extra-cellular $\mathrm{PGE}_{2}$ levels in IL1 $\beta$-/TNF $\alpha$-stimulated HeLa cells after $R$-flurbiprofen treatment (Figure 4A). Treatment of HeLa cells with IL1 $\beta / \mathrm{TNF} \alpha$ increased extracellular $\mathrm{PGE}_{2}$ already after $2 \mathrm{~h}$. Co-treatment with $10 \mu \mathrm{M} R$-flurbiprofen increased intracellular $\mathrm{PGE}_{2}$ levels and this was accompanied by a slight decrease in extracellular $\mathrm{PGE}_{2}$. Similar effects were observed at $8-24 \mathrm{~h}$, and were most pronounced at $16 \mathrm{~h}$. Hence, $R$-flurbiprofen blocked the export of $\mathrm{PGE}_{2}$, possibly by interfering with the membrane transporter MRP4. The flurbiprofen racemate was previously shown to inhibit MRP4 in the concentration range of 5-50 $\mu \mathrm{M}$ [25], fitting well to the concentration range that inhibited extracellular PGs in our experiments. Figure 4B,C show the expression of MRP4 in our cells; it was expressed highest in A549.

To assess if the effects of R-flurbiprofen depend on MRP4, we silenced MRP4 via siRNA transfection (Figure 5A mRNA and B protein). The knockdown resulted in intracellular trapping of $\mathrm{PGE}_{2}$ as expected (Figure $5 \mathrm{C}$ ), indicating that $\mathrm{PGE}_{2}$ export from our cells indeed depended on MRP4 and suggesting that it was the major $R$-flurbiprofen target.
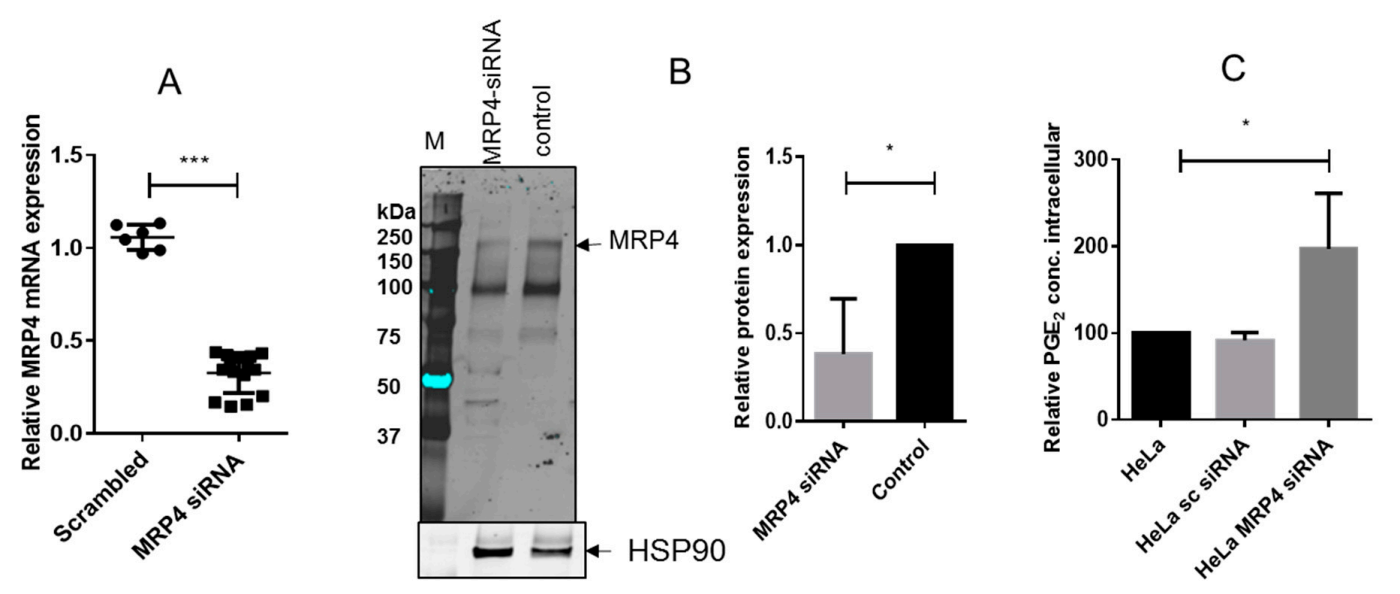

Figure 5. (A) MRP4 mRNA expression in HeLa cells after transfection of scrambled or MRP4 siRNA. Means \pm S.E.M. of three independent experiments, determined in triplicate, are shown. Statistical analysis was done with $t$-test; (B) Western blot analysis of MRP4 in MRP4 siRNA-treated HeLa cells and control cells: HSP90 was used as the loading control. One representative experiment out of three is shown, as well as the quantification of the three Western blots (MRP4/HSP90). Means \pm S.E.M. of three independent experiments. Statistical analysis was done with $t$-test; (C) Intracellular PGE $_{2}$ concentrations of stimulated HeLa cells after MRP4 siRNA treatment. HeLa cells were transfected with MRP4 siRNA or scrambled siRNA, and $24 \mathrm{~h}$ later stimulated with IL- $1 \beta(1 \mathrm{ng} / \mathrm{mL})$ and TNF $\alpha$ $(5 \mathrm{ng} / \mathrm{mL})$ for $16 \mathrm{~h}$. Intracellular $\mathrm{PGE}_{2}$ was determined by nano-LC-MS/MS. Means \pm S.E.M. of three experiments. Statistical analysis was done with one-way ANOVA. Significant $p$ values are shown as: $* * * \leq 0.001, * p \leq 0.05$.

\section{Discussion}

We show in the present study that $R$-flurbiprofen traps $\mathrm{PGE}_{2}$ inside of cells by inhibition of the multidrug resistance-associated protein, MRP4, which acts as a PG exporter. In addition, $R$-flurbiprofen mildly blocks the membrane translocation of $\mathrm{CPLA}_{2}$, which is triggered by intracellular calcium. Thereby, $R$-flurbiprofen limits the availability of the substrate, arachidonic acid, for COXs.

$R$-flurbiprofen has long been considered as the "inactive" enantiomer of flurbiprofen [26], owing to its failure to inhibit the catalytic activity of COXs. However, $R$-flurbiprofen has anti-nociceptive, anti-inflammatory, immune-modulatory and anti-carcinogenic effects and mildly protects animals in Alzheimer's models from a decline in cognitive functions [10,14,18,27-35].

The anti-carcinogenic effects of $R$-flurbiprofen in mice have been associated in part with the activation of c-Jun-N-terminal kinase, the accumulation of p53 and p75 (NTR) and/or the activation of 
protein kinase B (PKB/AKT) [3,10,36,37]. The analgesic effect of $R$-flurbiprofen is mediated in part via restoration of endogenous cannabinoids [27], mediated via inhibition of the degradation via FAAH or oxidatively via COXs $[38,39]$.

Our data now show that $R$-flurbiprofen inhibits the PG pathway in part by inhibition of cPLA $2 \alpha$ translocation to cell membranes, which occurred at a concentration of $100 \mu \mathrm{M}$, in the range of those found in the plasma of patients treated with $R$-flurbiprofen [18]. cPLA 2 is ubiquitously expressed and responsible for the very first step in prostaglandin synthesis. Therefore, $\mathrm{CPLA}_{2}$ inhibition is relevant for most cells.

Additionally, we found that $R$-flurbiprofen inhibits the MRP4-mediated export of PGs, and this effect is tissue- and possibly context-dependent because MRP4 expression is regulated by various stimuli such as estrogen [40] or xenobiotics in an age-dependent manner [41].

PGs are known to be substrates of human organic anion transporters such as OAT1, OAT3, the prostaglandin transporter (PGT) and MRP4, which import or export PGs, respectively. Inhibition of OAT1, OAT3 and MRP4 by $R$ - and $S$-flurbiprofen was previously reported [25,42]. However, $S$-flurbiprofen is somewhat more effective [25], but, importantly, $R$-flurbiprofen is not toxic whereas $S$-flurbiprofen leads to substantial damage of the gastrointestinal mucosa. MRP4 is highly expressed whereas PGT is mostly downregulated in various cancers, including the cancer cell lines used in the present study [43]. In gastric cancer cells, the inhibition of MRP4 via RNAi-mediated silencing was associated with reduced cell proliferation [44], indicating that MRP4 contributes to cancer growth, possibly via the export of PGs, which are well known to promote cancer proliferation and angiogenesis [45-48]. Furthermore, overexpression of MRP4 is associated with multidrug resistance against a number of chemotherapeutics, which are substrates of MRP4 [49]. Hence, $R$-flurbiprofen, likely acts as an inhibitor of these $A B C$ transporters, and thereby may reduce tumor growth; however, unfortunately, in clinical studies of prostate cancer, $R$-flurbiprofen failed despite the well-documented beneficial effects of COX inhibition in cancer patients [50,51]. However, because of its low /lack of toxicity, $R$-flurbiprofen $[52,53]$ is still an enigmatic candidate substance, for which the right indication may not be cancer but possibly immune-mediated diseases, the latter suggested by a recent study showing that $R$-flurbiprofen prevented the development of autoimmune encephalomyelitis in mice, which is a model for multiple sclerosis (MS) [30]. Although MS is likely not a PG-driven disease in humans, MRP4 may be involved in the PG-dependent transmigration of immune cells at the blood-brain barrier, where MRP4 and EP receptors are expressed [54,55]. Elucidation of its mechanism may therefore help to design related, more powerful substances. Moreover, very recently, MRP4 inhibition has been considered as a potential pharmacologic target for cardiovascular diseases [56,57].

In summary, our data show that $R$-flurbiprofen reduces extracellular PGs in various cancer cell lines at physiological concentrations. It inhibits the translocation of CPLA2 $\alpha$ to its active site at the cell membrane and it blocks PG export via inhibition of the PG exporter, MRP4. These are novel mechanisms of $R$-flurbiprofen, which may unravel new indications for this enigmatic, non-toxic anti-nociceptive, anti-inflammatory, immune-modulating and anti-cancerous drug.

\section{Materials and Methods}

\subsection{Cells and Reagents}

HCA-7 (human colon carcinoma) cells were purchased from the European Collection of Cell Cultures (ECC, Salisbury, UK), HeLa (human cervix carcinoma) cells from the Deutsche Sammlung für Mikroorganismen und Zellkulturen (DSMZ, Braunschweig, Germany) and A-549 (human lung carcinoma) cells from the Cell Bank of the JCRB (Japanese Collection of Research Bioresources)/HSRRB (Human Science Research Resources Bank). HCA-7 and A-549 cells were cultured in DMEM (Dulbecco's modified Eagle's medium) whereas HeLa cells were cultured in RPMI medium 1640. All media contained high glucose, GlutaMAX, 10\% FCS, and were purchased from Invitrogen (Karlsruhe, Germany) as well as 100 units $/ \mathrm{mL}$ penicillin $\mathrm{G}$ and $100 \mu \mathrm{g} / \mathrm{mL}$ streptomycin. Cells were cultured at $37^{\circ} \mathrm{C}$ in an atmosphere 
containing $5 \% \mathrm{CO}_{2}$. R- and S-flurbiprofen were supplied by PAZ Arzneimittelentwicklungsgesellschaft (Bad Oeynhausen, Germany). The optical purity of both enantiomers was $98 \%$ (determined by stereoselective HPLC-analysis). Recombinant human IL-1 beta (IL-1 $\beta$ ) and recombinant human tumor necrosis factor alpha (TNF $\alpha$ ) were purchased from PeproTech (Hamburg, Germany). Calcium ionophore A23187 was purchased from Sigma-Aldrich (Seelze, Germany). cPLA ${ }_{2 \alpha}$ inhibitor was purchased from Calbiochem, (La Jolla, CA, USA), SC-560 and celecoxib were synthesized by WITEGA Laboratorien (Berlin-Adlershof GmbH, Germany), MK-886 was purchased from Cayman, (Ann Arbor, MI, USA) and acetylsalicylic acid was purchased from Sigma-Aldrich.

\subsection{COX Inhibitor Screening Assay}

Inhibition of COX-1 (ovine) and COX-2 (human recombinant) activity by flurbiprofen was measured using a COX Inhibitor Screening Assay Kit (Cayman Chemicals), according to the manufacturer's protocol. SC-560, a selective COX-1 inhibitor, and celecoxib, a selective COX-2 inhibitor, were used as positive controls. The assay was started by the conversion of arachidonic acid as a substrate of the COX enzymes to $\mathrm{PGH}_{2}$ which is further reduced by $\mathrm{SnCl}_{2}$ and $\mathrm{HCl}$ to different prostaglandins such as $\mathrm{PGE}_{2}, \mathrm{PGD}_{2}$ and $\mathrm{PGF}_{2 \alpha}$. At the end of the reaction, the samples were centrifuged at $10,000 \times g$ and room temperature (RT) for $5 \mathrm{~min}$, and the supernatant was diluted with methanol (1:5). In contrast to the manufacturer's protocol, the amounts of PGs were quantified by LC-MS/MS analysis using deuterated prostaglandins as internal standards $\left(\left[{ }^{2} \mathrm{H}_{4}\right]-\mathrm{PGE}_{2},\left[{ }^{2} \mathrm{H}_{4}\right]-\mathrm{PGD}_{2}\right.$, $\left[{ }^{2} \mathrm{H}_{4}\right]-\mathrm{TXB}_{2},\left[{ }^{2} \mathrm{H}_{4}\right]-\mathrm{PGF}_{2 \alpha}$, and $\left[{ }^{2} \mathrm{H}_{4}\right]-6-$ keto-PGF $\left.1 \alpha\right)$. Then $100 \mu$ L EDTA $(0.15 \mathrm{M}), 20 \mu \mathrm{L}$ methanol, and $20 \mu \mathrm{L}$ internal standard solution were further added to $70 \mu \mathrm{L}$ sample solution. LC-MS/MS sample preparation was done by liquid-liquid extraction with ethyl acetate $(2 \times 600 \mu \mathrm{L})$. After evaporation, the residue obtained was reconstituted with $50 \mu \mathrm{L}$ acetonitrile/water/formic acid (20:80:0.0025, $v / v)$.

\subsection{Analysis of Prostaglandin Levels ( $P G E_{2}, P G D_{2}$ and $\left.P G F_{2 \alpha}\right)$}

Cells were incubated for $24 \mathrm{~h}$ at $37^{\circ} \mathrm{C}$ in medium containing $10 \% \mathrm{FCS}$. The medium was replaced with fresh medium containing either $S$-flurbiprofen $(0.01-10 \mu \mathrm{M})$ or $R$-flurbiprofen $(0.03-50 \mu \mathrm{M})$ and, simultaneously, IL-1 $\beta(2 \mathrm{ng} / \mathrm{mL})$ for stimulation of A-549 cells, IL- $1 \beta(1 \mathrm{ng} / \mathrm{mL})+\mathrm{TNF} \alpha(5 \mathrm{ng} / \mathrm{mL})$ for stimulation of HeLa cells. HCA-7 cells produce high amounts of $\mathrm{PGE}_{2}$ without stimulation, therefore, we pre-incubated HCA-7 cells with medium containing either PBS or $R$-flurbiprofen $(0.03-50 \mu \mathrm{M})$ for $1 \mathrm{~h}$ and replaced this medium, thereafter, with fresh medium and the same additions. This procedure ensured that all $\mathrm{PGE}_{2}$ produced by these cells was removed, before flurbiprofen had exerted full activity. After incubation for $16 \mathrm{~h}$, the cells and the supernatant were collected and briefly centrifuged. The amount of $\mathrm{PGE}_{2}$ in cell lysate and the supernatant was determined using the $\mathrm{PGE}_{2}$ Correlate EIATM-Kit (Assay Designs Inc., Ann Arbor, MI, USA), according to the manufacturer's protocol. In addition, the levels of $\mathrm{PGE}_{2}, \mathrm{PGD}_{2}$ and $\mathrm{PGF}_{2 \alpha}$ were measured by LC-MS/MS analysis according to previous publications $[58,59]$.

For measurement of intracellular $\mathrm{PGE}_{2}$ levels cells were washed with ice-cold PBS, resuspended in Tris-CHAPS-buffer (10 mM Tris pH 7.4, 20 mM CHAPS (3-[(3-Cholamidopropyl)dimethylammonio] -1-propanesulfonate, AppliChem GmbH, Germany) , $0.5 \mathrm{mM}$ EDTA (Ethylenediaminetetraacetic acid, Sigma Aldrich, Deisenhofen, Germany), 0.5 mM PMSF (Phenylmethylsulfonyl fluoride, AppliChem GmbH, Darmstadt, Germany), 1 mM DTT (Dithiothreitol, Sigma Aldrich), 2 mM Pefabloc ${ }^{\circledR}$ SC, Sigma Aldrich) and sonicated with an Branson sonifier 250. Thereafter, cell-lysate was centrifuged at 14,000 rpm, $45 \mathrm{~min}, 4^{\circ} \mathrm{C}$. $\mathrm{PGE}_{2}$ was quantified using nano liquid chromatography tandem mass spectrometry as described before [60].

\subsection{Human Whole-Blood Assay In Vitro}

The human whole blood assay was performed as described previously [61]. Briefly, for induction of COX-1 activity, aliquots of freshly heparinized human blood $(1 \mathrm{~mL})$ obtained from healthy male and female informed volunteers were pre-incubated with $R$-flurbiprofen or vehicle (DMSO) for $10 \mathrm{~min}$ 
at $37^{\circ} \mathrm{C}$. Formation of thromboxane $\mathrm{B}_{2}\left(\mathrm{TXB}_{2}\right)$ by COX-1 was initiated by the addition of $2.5 \mu \mathrm{L}$ calcium ionophore A23187 (20 mM in DMSO) to obtain a final concentration of $50 \mu \mathrm{M}$ (final DMSO concentration was $<1 \%$ ). The reaction was terminated after $30 \mathrm{~min}$ by rapid cooling of the plate on ice. For induction of COX-2 activity, aliquots of freshly heparinized human blood (1 mL) were pre-incubated with $10 \mu \mathrm{L}$ acetylsalicylic acid (ASS, $1 \mathrm{mg} / \mathrm{mL}$ in PBS; inhibits COX-1 derived $\mathrm{PGE}_{2}$ ) and $R$-flurbiprofen or DMSO for $10 \mathrm{~min}$ at $37^{\circ} \mathrm{C}$. $\mathrm{PGE}_{2}$ formation by COX-2/mPGES- 1 was stimulated by adding $2 \mu \mathrm{L}$ lipopolysaccharide (LPS, $5 \mathrm{mg} / \mathrm{mL}$ in PBS). The reaction was terminated after $24 \mathrm{~h}$ by rapid cooling of the plate on ice. The samples were centrifuged at $450 \times \mathrm{g}$ and $4{ }^{\circ} \mathrm{C}$ for $20 \mathrm{~min}$. SC-560 (COX-1 inhibitor) and celecoxib (COX-2 inhibitor) were used as controls $\mathrm{TXB}_{2}$ and $\mathrm{PGE}_{2}$ in the plasma supernatant (200 $\mu \mathrm{L}$ sample size) were analyzed as described above.

\section{5. mPGES-1 Activity Assay}

In order to investigate the impact of $R$-flurbiprofen on mPGES-1 activity in vitro, the microsomal fraction of HeLa cells was prepared. Approximately $4 \times 10^{6}$ cells were incubated for $24 \mathrm{~h}$ at $37^{\circ} \mathrm{C}$ in medium containing $10 \%$ FCS. The medium was removed and cells were stimulated with IL-1 $\beta$ $(1 \mathrm{ng} / \mathrm{mL})+\mathrm{TNF} \alpha(5 \mathrm{ng} / \mathrm{mL})$ for $16 \mathrm{~h}$. After washing with $10 \mathrm{~mL}$ PBS, cells were scraped in $2 \mathrm{~mL}$ PBS and centrifuged at $2500 \times g$ for $2 \mathrm{~min}$ at $4{ }^{\circ} \mathrm{C}$. Cell pellets were resuspended in $600 \mu \mathrm{L}$ potassium phosphate buffer (Kpi-buffer; $0.1 \mathrm{M}$; pH 7.4), containing $1 \times$ CompleteTM protease inhibitor cocktail (Roche Diagnostics, Mannheim, Germany), sucrose (0.25 M) and reduced glutathione (GSH; $1 \mathrm{mM})$. Samples were sonicated and centrifuged at $150,000 \times g$ for $1 \mathrm{~h}$ at $4{ }^{\circ} \mathrm{C}$. The microsomal fraction (pellet) was resuspended in $50 \mu \mathrm{L}$ Kpi-buffer $(0.1 \mathrm{M}, \mathrm{pH} 7.4)$, containing $1 \times$ CompleteTM and reduced GSH $(2.5 \mathrm{mM})$ and total protein content was measured using the Bradford method.

The mPGES-1 activity assay was performed as described by Thoren et al. [62]. The amount of $\mathrm{PGE}_{2}$ produced was measured by LC-MS/MS as described above.

\subsection{Western Blot Analysis}

Cells were seeded in medium containing $10 \%$ FCS and treated as indicated in the Figure legends. mPGES-1 and mPGES-2 protein was analysed in the microsomal fraction prepared as described in Section 4.5. cPGES and mPGES-2 proteins were detected in the cytosolic fraction. $\mathrm{cPLA}_{2 \alpha}$ and COX-1/-2 proteins were detected in whole cell lysates.

For cPLA $2 \alpha$ translocation experiments, A-549 cells were seeded at a density of $1.8 \times 10^{6}$ cells per dish, respectively, in medium containing $10 \%$ FCS and incubated for $24 \mathrm{~h}$ at $37^{\circ} \mathrm{C}$. Cells were then pre-incubated with $R$-flurbiprofen $(100 \mu \mathrm{m})$ for $30 \mathrm{~min}$. Afterwards, cells were stimulated with calcium ionophore A23187 $(5 \mu \mathrm{M})$ for 10, 30 and $60 \mathrm{~min}$ and simultaneously treated with $R$-flurbiprofen $(100 \mu \mathrm{m})$. After harvesting, the cells were separated into membrane and cytosolic fractions by centrifugation. The cPLA $2 \alpha$ protein was analyzed in both fractions. MRP4 was detected in whole cell extract from HeLa, A549, and HCA-7 cells.

Immunoblotting was performed as described previously [63]. Primary antibodies directed against mPGES-1 (rabbit polyclonal; Agrisera, Vännäs, Sweden), COX-2, cPLA $2 \alpha$ (goat polyclonal; Santa Cruz, Heidelberg), COX-1 (mouse monoclonal) mPGES-2, cPGES, MRP4 (goat polyclonal; Acris, Herford) were used. Anti- $\beta$-actin antibody (mouse monoclonal; Sigma-Aldrich) or anti-HSP90 antibody (mouse monoclonal, BD Bioscience, Heidelberg, Germany) were used as loading controls. Thereafter the membranes were incubated with secondary antibodies coupled to fluorescence dyes with an emission at 700 or $800 \mathrm{~nm}$ and detected with the Odyssey infrared imager.

\section{7. cPLA $A_{2 \alpha}$ Activity Assay}

$\mathrm{CPLA}_{2 \alpha}$ enzyme was overexpressed and isolated from Sf9-insekt cells, as described previously [64]. Multilamellar vesicles (MLVs) were prepared by drying 1-palmitoyl-2 arachidonyl-sn-glycero-3phosphocholine (PAPC, $10 \mathrm{mg} / \mathrm{mL}$ in chloroform) and 1-palmitoyl-2oleoyl-sn-glycerol (POG, $10 \mathrm{mg} / \mathrm{mL}$ in chloroform) 2:1 under nitrogen. Vesicle buffer (134 mM NaCl, $20 \mathrm{mM}$ Tris-HCl pH 7.4) 
was added and lipids were subjected to freezing/thawing cycles (liquid N2). For the in vitro cPLA $2 \alpha$ activity assay, small unilamellar vesicles (SUVs, $15-50 \mathrm{~nm}$ ) were used. For this, MLVs were further downsized to SUVs by sonication for $15 \mathrm{~min}$.

For the assay, $190 \mu \mathrm{L}$ vesicle solution were mixed with DMSO (positive control), $5 \mu \mathrm{M}$ cPLA $2 \alpha$-inhibitor (assay control) or $R$-flurbiprofen $\left(0.1-1000 \mu \mathrm{M}\right.$ ). One $\mathrm{mM} \mathrm{CaCl}_{2}$ and $200 \mathrm{ng} \mathrm{cPLA}_{2 \alpha}$ enzyme preparation were added and the assay mixture was incubated for $60 \mathrm{~min}$ at $37^{\circ} \mathrm{C}$. As negative control, $190 \mu \mathrm{L}$ vesicle solution were mixed with DMSO, $1 \mathrm{mM} \mathrm{CaCl}_{2}$ without cPLA ${ }_{2 \alpha}$ enzyme and also incubated for $60 \mathrm{~min}$ (background control for the non-enzymatic release of arachidonic acid from vesicles). The reaction was stopped by adding $1.6 \mathrm{~mL}$ ice-cold $\mathrm{MeOH}$ to each reaction tube.

For the determination of arachidonic acid by LC-MS/MS an arachidonic acid working standard within a concentration range from 0.1 to $500 \mathrm{ng} / \mathrm{mL}$ was prepared in methanol, lower limit of quantification (LLOQ) was $0.1 \mathrm{ng} / \mathrm{mL}$. Samples for standard curve and quality control were prepared with $150 \mu \mathrm{L}$ of blank medium, $20 \mu \mathrm{L}$ working standards and $20 \mu \mathrm{L}$ internal standards solution $\left[{ }^{2} \mathrm{H}_{8}\right]$-AA in methanol. Medium samples were prepared similarly, instead of $150 \mu \mathrm{L}$ blank medium and $20 \mu \mathrm{L}$ working standard $150 \mu \mathrm{L}$ sample and $20 \mu \mathrm{L}$ methanol were added. Arachidonic acid and internal standard were extracted with liquid-liquid-extraction. Therefore, the samples were extracted twice with $600 \mu \mathrm{L}$ ethyl acetate. The organic phase was removed at a temperature of $45^{\circ} \mathrm{C}$ under a gentle stream of nitrogen. The residues were reconstituted with $50 \mu \mathrm{L}$ acetonitrile/water/formic acid (20:80:0.0025, $v / v, \mathrm{pH} 4.0)$, centrifuged for $2 \mathrm{~min}$ at 10,000 $\times g$ and then transferred to glass vials (Macherey-Nagel, Düren, Germany). The content of arachidonic acid (AA) in this solution was determined by liquid chromatography-electrospray ionization-tandem mass spectrometry (LC-ESI-MS/MS). Arachidonic acid was analyzed with a Synergi Hydro-RP column $(20 \times 2 \mathrm{~mm}$ I.D, $2 \mu \mathrm{m}$ particle size from phenomenex, Aschaffenburg, Germany) and determined with an API 4000 (Sciex, Darmstadt, Germany). Data acquisition and quantification were done using Analyst Software V 1.5 employing the internal standard method (isotope dilution mass spectrometry).

\subsection{Silencing of $M R P 4$}

MRP4 was silenced in HeLa cells using siRNA. HeLa cells were transfected with either $10 \mu \mathrm{M}$ MRP4 siRNA (Santa Cruz, Heidelberg, Germany) or scrambled siRNA (Ambion, Thermo Fisher Scientific GmbH, Schwerte, Germany) using siPortTM NeoFXTM Transfection Agent (Invitrogen, Thermo Fisher Scientific GmbH, Schwerte, Germany). After $24 \mathrm{~h}$ cells were harvested and either whole protein-extract was prepared and separated by Western blot (see above) or mRNA was extracted for quantitative RT-PCR (see below).

\subsection{Quantitative Real-Time-PCR}

Total RNA was isolated, using TRI reagent [65] and Phase Lock Gel Light tubes (5 Prime, Gaithersburg, MD, USA). RNA concentrations were determined photometrically using the NanoDrop-spectrometer (Peqlab Biotechnologie, Erlangen, Germany). cDNA was synthesized from $200 \mathrm{ng}$ total RNA using the VERSOTM cDNA Kit (Thermo Fisher, ABgene, Epsom, UK). Gene specific PCR products were assayed using Maxima SYBR Green qPCR Master Mix $(2 \times)$ with $10 \mathrm{nM}$ ROX Solution (Thermo Fisher) on a 7500 fast quantitative PCR system (TaqMan ${ }^{\circledR}$, Life Technologies, Darmstadt, Germany). Relative gene expression was determined using the comparative CT (cycle threshold) method, normalizing relative values to the expression level of RPL37A (RPL37A forward 5'-AGGAACCACAGTGCCAGATCC-3', RPL37A reverse 5'-ATTGAAATCAGCCAGCACGC-3') as a housekeeping gene. Primers for the determination of MRP4 (MRP4 forward 5'-GGACAAAGACAAC TGGTGTGCC-3' ', MRP4 reverse 5'-AATGGTTAGCACGGTGCAGTGG-3') and RPL37A expression were synthesized by MWG (Ebersberg, Germany). 


\subsection{Statistics}

The SPSS 9.01 computer software and GraphPad Prism 6.0 were used for statistical analyses. Data are presented as means \pm S.E.M (standard error of the mean). IC $_{50}$ values were analysed using a sigmoid Emax model followed by subsequent submission to univariate analysis of variance (ANOVA) and $t$-tests using a Bonferroni $\alpha$-correction for multiple comparisons, $\alpha$ was set at 0.05 . Significant $p$ values are shown as: ${ }^{* *} p \leq 0.001,{ }^{* *} p \leq 0.01,{ }^{*} p \leq 0.05$. The number of experiments is specified in the figure legends.

Acknowledgments: This work was supported by the Deutsche Forschungsgemeinschaft (DFG) SFB 1039, DFG project GR2011/3-1, DFG project GR2011/3-2 and the LOEWE Research Centre for Translational Medicine and Pharmacology.

Author Contributions: Ivonne Wobst, Lisa Ebert, Kerstin Birod, Marthe-Susanna Wegner conducted the cell culture experiment, activity assay, RT-PCR, Western Blot and immunohistochemistry, and performed data analysis. Marika Hoffmann and Dieter Steinhilber provided the method and tools for the cPLA 2 activity assay. Dominique Thomas and Carlo Angioni were responsible for LC-MS/MS measurements. Michael J. Parnham, Irmgard Tegeder, Gerd Geisslinger and Sabine Grösch designed the study, were involved in data interpretation and preparation of the manuscript.

Conflicts of Interest: The authors declare no conflict of interest.

\section{Abbreviations}

$\begin{array}{ll}\text { cPLA } & \text { cytosolic phospholipase } \mathrm{A}_{2} \\ \text { COX-1 } & \begin{array}{l}\text { cyclooxygenase-1 } \\ \text { cyclooxygenase }-2\end{array} \\ \text { COX-2 } & \text { interleukin-1 beta } \\ \text { IL-1 } \beta & \text { multidrug resistance protein } 4 \\ \text { MRP4 } & \text { non-steroidal anti-inflammatory drugs } \\ \text { NSAIDs } & \text { prostaglandin } \\ \text { PG } & \text { PGE-synthases } \\ \text { PGES } & \text { prostaglandin transporter } \\ \text { PGT } & \text { 15-hydroxyprostaglandin dehydrogenase } \\ \text { 15-PGDH } & \text { tumor necrosis factor alpha }\end{array}$

\section{References}

1. Funk, C.D. Prostaglandins and leukotrienes: Advances in eicosanoid biology. Science 2001, 294, 1871-1875. [CrossRef] [PubMed]

2. Chalmers, I.M.; Cathcart, B.J;; Kumar, E.B.; Dick, W.C.; Buchanan, W.W. Clinico-pharmacological studies and clinical evaluation of flurbiprofen. A new non-steroidal antirheumatic agent. Ann. Rheum. Dis. 1972, 31, 319-324. [CrossRef] [PubMed]

3. Grosch, S.; Tegeder, I.; Schilling, K.; Maier, T.J.; Niederberger, E.; Geisslinger, G. Activation of c-Jun-Nterminal-kinase is crucial for the induction of a cell cycle arrest in human colon carcinoma cells caused by flurbiprofen enantiomers. FASEB J. 2003, 17, 1316-1318. [CrossRef] [PubMed]

4. Tegeder, I.; Niederberger, E.; Israr, E.; Guhring, H.; Brune, K.; Euchenhofer, C.; Grosch, S.; Geisslinger, G. Inhibition of NF-KB and AP-1 activation by $R$ - and S-flurbiprofen. FASEB J. 2001, 15, 595-597. [PubMed]

5. Geisslinger, G.; Schaible, H.G. New insights into the site and mode of antinociceptive action of flurbiprofen enantiomers. J. Clin. Pharmacol. 1996, 36, 513-520. [CrossRef] [PubMed]

6. Malmberg, A.B.; Yaksh, T.L. Antinociception produced by spinal delivery of the $S$ and $R$ enantiomers of flurbiprofen in the formalin test. Eur. J. Pharmacol. 1994, 256, 205-209. [CrossRef]

7. Shieh, W.R.; Chen, C.S. Purification and characterization of novel "2-arylpropionyl-CoA epimerases" from rat liver cytosol and mitochondria. J. Biol. Chem. 1993, 268, 3487-3493. [PubMed]

8. Leaper, D.J.; French, B.; Bennett, A. Reduction by flurbiprofen of primary tumor growth and local metastasis formation in mice. Adv. Prostaglandin Thromboxane Res. 1980, 6, 591-593. [PubMed]

9. Waddell, W.R.; Loughry, R.W. Sulindac for polyposis of the colon. J. Surg. Oncol. 1983, 24, 83-87. [CrossRef] [PubMed] 
10. Grosch, S.; Schilling, K.; Janssen, A.; Maier, T.J.; Niederberger, E.; Geisslinger, G. Induction of apoptosis by $R$-flurbiprofen in human colon carcinoma cells: Involvement of p53. Biochem. Pharmacol. 2005, 69, 831-839. [CrossRef] [PubMed]

11. Schmassmann, A. Mechanisms of ulcer healing and effects of nonsteroidal anti-inflammatory drugs. Am. J. Med. 1998, 104, 43S-51S. [CrossRef]

12. Rossat, J.; Maillard, M.; Nussberger, J.; Brunner, H.R.; Burnier, M. Renal effects of selective cyclooxygenase-2 inhibition in normotensive salt-depleted subjects. Clin. Pharmacol. Ther. 1999, 66, 76-84. [CrossRef]

13. Bresalier, R.S.; Sandler, R.S.; Quan, H.; Bolognese, J.A.; Oxenius, B.; Horgan, K.; Lines, C.; Riddell, R.; Morton, D.; Lanas, A.; et al. Cardiovascular events associated with rofecoxib in a colorectal adenoma chemoprevention trial. N. Engl. J. Med. 2005, 352, 1092-1102. [CrossRef] [PubMed]

14. Geisslinger, G.; Muth-Selbach, U.; Coste, O.; Vetter, G.; Schrodter, A.; Schaible, H.G.; Brune, K.; Tegeder, I. Inhibition of noxious stimulus-induced spinal prostaglandin E2 release by flurbiprofen enantiomers: A microdialysis study. J. Neurochem. 2000, 74, 2094-2100. [CrossRef] [PubMed]

15. Peskar, B.M.; Kluge, S.; Peskar, B.A.; Soglowek, S.M.; Brune, K. Effects of pure enantiomers of flurbiprofen in comparison to racemic flurbiprofen on eicosanoid release from various rat organs ex vivo. Prostaglandins 1991, 42, 515-531. [CrossRef]

16. Oelkers, R.; Neupert, W.; Williams, K.M.; Brune, K.; Geisslinger, G. Disposition and effects of flurbiprofen enantiomers in human serum and blister fluid. Br. J. Clin. Pharmacol. 1997, 43, 145-153. [CrossRef] [PubMed]

17. Green, R.C.; Schneider, L.S.; Amato, D.A.; Beelen, A.P.; Wilcock, G.; Swabb, E.A.; Zavitz, K.H.; Tarenflurbil Phase 3 Study Group. Effect of tarenflurbil on cognitive decline and activities of daily living in patients with mild Alzheimer disease: A randomized controlled trial. JAMA 2009, 302, 2557-2564. [CrossRef] [PubMed]

18. Galasko, D.R.; Graff-Radford, N.; May, S.; Hendrix, S.; Cottrell, B.A.; Sagi, S.A.; Mather, G.; Laughlin, M.; Zavitz, K.H.; Swabb, E.; et al. Safety, tolerability, pharmacokinetics, and Abeta levels after short-term administration of $R$-flurbiprofen in healthy elderly individuals. Alzheimer Dis. Assoc. Disord. 2007, 21, 292-299. [CrossRef] [PubMed]

19. Brenneis, C.; Maier, T.J.; Schmidt, R.; Hofacker, A.; Zulauf, L.; Jakobsson, P.J.; Scholich, K.; Geisslinger, G. Inhibition of prostaglandin E2 synthesis by SC-560 is independent of cyclooxygenase 1 inhibition. FASEB J. 2006, 20, 1352-1360. [CrossRef] [PubMed]

20. Diez, E.; Louis-Flamberg, P.; Hall, R.H.; Mayer, R.J. Substrate specificities and properties of human phospholipases A2 in a mixed vesicle model. J. Biol. Chem. 1992, 267, 18342-18348. [PubMed]

21. Leslie, C.C. Regulation of the specific release of arachidonic acid by cytosolic phospholipase A2. Prostaglandins Leukot. Essent. Fatty Acids 2004, 70, 373-376. [CrossRef] [PubMed]

22. Reid, G.; Wielinga, P.; Zelcer, N.; van der Heijden, I.; Kuil, A.; de Haas, M.; Wijnholds, J.; Borst, P. The human multidrug resistance protein MRP4 functions as a prostaglandin efflux transporter and is inhibited by nonsteroidal antiinflammatory drugs. Proc. Natl. Acad. Sci. USA 2003, 100, 9244-9249. [CrossRef] [PubMed]

23. Schuster, V.L. Prostaglandin transport. Prostaglandins Other Lipid Mediat. 2002, 68-69, 633-647. [CrossRef]

24. Chan, B.S.; Bao, Y.; Schuster, V.L. Role of conserved transmembrane cationic amino acids in the prostaglandin transporter PGT. Biochemistry 2002, 41, 9215-9221. [CrossRef] [PubMed]

25. Kawase, A.; Yamamoto, T.; Egashira, S.; Iwaki, M. Stereoselective inhibition of methotrexate excretion by glucuronides of nonsteroidal anti-inflammatory drugs via multidrug resistance proteins 2 and 4. J. Pharmacol. Exp. Ther. 2016, 356, 366-374. [CrossRef] [PubMed]

26. Mayer, J.M. Stereoselective metabolism of anti-inflammatory 2-arylpropionates. Acta Pharm. Nord. 1990, 2, 197-216. [PubMed]

27. Bishay, P.; Schmidt, H.; Marian, C.; Haussler, A.; Wijnvoord, N.; Ziebell, S.; Metzner, J.; Koch, M.; Myrczek, T.; Bechmann, I.; et al. $R$-flurbiprofen reduces neuropathic pain in rodents by restoring endogenous cannabinoids. PLoS ONE 2010, 5, E10628. [CrossRef] [PubMed]

28. Geisslinger, G.; Ferreira, S.H.; Menzel, S.; Schlott, D.; Brune, K. Antinociceptive actions of $R(-)-$ flurbiprofen-A non-cyclooxygenase inhibiting 2-arylpropionic acid-in rats. Life Sci. 1994, 54, L173-L177. [CrossRef]

29. Lotsch, J.; Geisslinger, G.; Mohammadian, P.; Brune, K.; Kobal, G. Effects of flurbiprofen enantiomers on pain-related chemo-somatosensory evoked potentials in human subjects. Br. J. Clin. Pharmacol. 1995, 40, 339-346. [CrossRef] [PubMed] 
30. Schmitz, K.; de Bruin, N.; Bishay, P.; Mannich, J.; Haussler, A.; Altmann, C.; Ferreiros, N.; Lotsch, J.; Ultsch, A.; Parnham, M.J.; et al. R-flurbiprofen attenuates experimental autoimmune encephalomyelitis in mice. EMBO Mol. Med. 2014, 6, 1398-1422. [CrossRef] [PubMed]

31. McCracken, J.D.; Wechter, W.J.; Liu, Y.; Chase, R.L.; Kantoci, D.; Murray, E.D., Jr.; Quiggle, D.D.; Mineyama, Y. Antiproliferative effects of the enantiomers of flurbiprofen. J. Clin. Pharmacol. 1996, 36, 540-545. [CrossRef] [PubMed]

32. Wechter, W.J.; Kantoci, D.; Murray, E.D., Jr.; Quiggle, D.D.; Leipold, D.D.; Gibson, K.M.; McCracken, J.D. $R$-flurbiprofen chemoprevention and treatment of intestinal adenomas in the APC(Min)/+ mouse model: Implications for prophylaxis and treatment of colon cancer. Cancer Res. 1997, 57, 4316-4324. [PubMed]

33. Wechter, W.J.; Leipold, D.D.; Murray, E.D., Jr.; Quiggle, D.; McCracken, J.D.; Barrios, R.S.; Greenberg, N.M. E-7869 (R-flurbiprofen) inhibits progression of prostate cancer in the TRAMP mouse. Cancer Res. 2000, 60, 2203-2208. [PubMed]

34. Wechter, W.J.; Murray, E.D., Jr.; Kantoci, D.; Quiggle, D.D.; Leipold, D.D.; Gibson, K.M.; McCracken, J.D. Treatment and survival study in the C57BL/6J-APC(Min)/+(Min) mouse with R-flurbiprofen. Life Sci. 2000, 66, 745-753. [CrossRef]

35. Eriksen, J.L.; Sagi, S.A.; Smith, T.E.; Weggen, S.; Das, P.; McLendon, D.C.; Ozols, V.V.; Jessing, K.W.; Zavitz, K.H.; Koo, E.H.; et al. NSAIDs and enantiomers of flurbiprofen target $\gamma$-secretase and lower Abeta 42 in vivo. J. Clin. Investig. 2003, 112, 440-449. [CrossRef] [PubMed]

36. Zemskova, M.; Wechter, W.; Bashkirova, S.; Chen, C.S.; Reiter, R.; Lilly, M.B. Gene expression profiling in $R$-flurbiprofen-treated prostate cancer: $R$-Flurbiprofen regulates prostate stem cell antigen through activation of AKT kinase. Biochem. Pharmacol. 2006, 72, 1257-1267. [CrossRef] [PubMed]

37. Quann, E.J.; Khwaja, F.; Zavitz, K.H.; Djakiew, D. The aryl propionic acid R-flurbiprofen selectively induces p75NTR-dependent decreased survival of prostate tumor cells. Cancer Res. 2007, 67, 3254-3262. [CrossRef] [PubMed]

38. Duggan, K.C.; Hermanson, D.J.; Musee, J.; Prusakiewicz, J.J.; Scheib, J.L.; Carter, B.D.; Banerjee, S.; Oates, J.A.; Marnett, L.J. (R)-Profens are substrate-selective inhibitors of endocannabinoid oxygenation by COX-2. Nat. Chem. Biol. 2011, 7, 803-809. [CrossRef] [PubMed]

39. Hermanson, D.J.; Gamble-George, J.C.; Marnett, L.J.; Patel, S. Substrate-selective COX-2 inhibition as a novel strategy for therapeutic endocannabinoid augmentation. Trends Pharmacol. Sci. 2014, 35, 358-367. [CrossRef] [PubMed]

40. Zhou, T.; Hu, M.; Pearlman, A.; Rohan, L.C. Expression, regulation, and function of drug transporters in cervicovaginal tissues of a mouse model used for microbicide testing. Biochem. Pharmacol. 2016, 116, 162-175. [CrossRef] [PubMed]

41. Li, C.Y.; Renaud, H.J.; Klaassen, C.D.; Cui, J.Y. Age-specific regulation of drug-processing genes in mouse liver by ligands of xenobiotic-sensing transcription factors. Drug Metab. Dispos. 2016, 44, 1038-1049. [CrossRef] [PubMed]

42. Honjo, H.; Uwai, Y.; Aoki, Y.; Iwamoto, K. Stereoselective inhibitory effect of flurbiprofen, ibuprofen and naproxen on human organic anion transporters hOAT1 and hOAT3. Biopharm. Drug Dispos. 2011, 32, 518-524. [CrossRef] [PubMed]

43. Holla, V.R.; Backlund, M.G.; Yang, P.; Newman, R.A.; DuBois, R.N. Regulation of prostaglandin transporters in colorectal neoplasia. Cancer Prev. Res. 2008, 1, 93-99. [CrossRef] [PubMed]

44. Chen, L.; Gu, J.; Xu, L.; Qu, C.; Zhang, Y.; Zhang, W. RNAi-mediated silencing of ATP-binding cassette C4 protein inhibits cell growth in MGC80-3 gastric cancer cell lines. Cell. Mol. Biol. 2014, 60, 1-5. [PubMed]

45. Eberhart, C.E.; Coffey, R.J.; Radhika, A.; Giardiello, F.M.; Ferrenbach, S.; DuBois, R.N. Up-regulation of cyclooxygenase 2 gene expression in human colorectal adenomas and adeno carcinomas. Gastroenterology 1994, 107, 1183-1188. [CrossRef]

46. Al-Kharusi, M.R.; Smartt, H.J.; Greenhough, A.; Collard, T.J.; Emery, E.D.; Williams, A.C.; Paraskeva, C. LGR5 promotes survival in human colorectal adenoma cells and is upregulated by PGE2: Implications for targeting adenoma stem cells with NSAIDs. Carcinogenesis 2013, 34, 1150-1157. [CrossRef] [PubMed]

47. Houchen, C.W.; Sturmoski, M.A.; Anant, S.; Breyer, R.M.; Stenson, W.F. Prosurvival and antiapoptotic effects of PGE2 in radiation injury are mediated by EP2 receptor in intestine. Am. J. Physiol. Gastrointest. Liver Physiol. 2003, 284, G490-G498. [CrossRef] [PubMed] 
48. Nakanishi, M.; Montrose, D.C.; Clark, P.; Nambiar, P.R.; Belinsky, G.S.; Claffey, K.P.; Xu, D.; Rosenberg, D.W. Genetic deletion of mPGES-1 suppresses intestinal tumorigenesis. Cancer Res. 2008, 68, 3251-3259. [CrossRef] [PubMed]

49. He, Z.; Hu, B.; Tang, L.; Zheng, S.; Sun, Y.; Sheng, Z.; Yao, Y.; Lin, F. The overexpression of MRP4 is related to multidrug resistance in osteosarcoma cells. J. Cancer Res. Ther. 2015, 11, 18-23. [PubMed]

50. Arber, N.; Kuwada, S.; Leshno, M.; Sjodahl, R.; Hultcrantz, R.; Rex, D. Sporadic adenomatous polyp regression with exisulind is effective but toxic: A randomised, double blind, placebo controlled, dose-response study. Gut 2006, 55, 367-373. [CrossRef] [PubMed]

51. Hakozaki, M.; Tajino, T.; Konno, S.; Kikuchi, S.; Yamada, H.; Yanagisawa, M.; Nishida, J.; Nagasawa, H.; Tsuchiya, T.; Ogose, A.; et al. Overexpression of cyclooxygenase-2 in malignant peripheral nerve sheath tumor and selective cyclooxygenase-2 inhibitor-induced apoptosis by activating caspases in human malignant peripheral nerve sheath tumor cells. PLoS ONE 2014, 9, E88035. [CrossRef] [PubMed]

52. Jerussi, T.P.; Caubet, J.F.; McCray, J.E.; Handley, D.A. Clinical endoscopic evaluation of the gastroduodenal tolerance to $(R)$-ketoprofen, $(R)$-flurbiprofen, racemic ketoprofen, and paracetamol: A randomized, single-blind, placebo-controlled trial. J. Clin. Pharmacol. 1998, 38, 19S-24S. [CrossRef] [PubMed]

53. Wilcock, G.K.; Black, S.E.; Hendrix, S.B.; Zavitz, K.H.; Swabb, E.A.; Laughlin, M.A.; Tarenflurbil Phase II Study Investigators. Efficacy and safety of tarenflurbil in mild to moderate Alzheimer's disease: A randomised phase II trial. Lancet Neurol. 2008, 7, 483-493. [CrossRef]

54. Uchida, Y.; Zhang, Z.; Tachikawa, M.; Terasaki, T. Quantitative targeted absolute proteomics of rat blood-cerebrospinal fluid barrier transporters: Comparison with a human specimen. J. Neurochem. 2015, 134, 1104-1115. [CrossRef] [PubMed]

55. Chapy, H.; Saubamea, B.; Tournier, N.; Bourasset, F.; Behar-Cohen, F.; Decleves, X.; Scherrmann, J.M.; Cisternino, S. Blood-brain and retinal barriers show dissimilar ABC transporter impacts and concealed effect of P-glycoprotein on a novel verapamil influx carrier. Br. J. Pharmacol. 2016, 173, 497-510. [CrossRef] [PubMed]

56. Belleville-Rolland, T.; Sassi, Y.; Decouture, B.; Dreano, E.; Hulot, J.S.; Gaussem, P.; Bachelot-Loza, C. MRP4 (ABCC4) as a potential pharmacologic target for cardiovascular disease. Pharmacol. Res. 2016, 107, 381-389. [CrossRef] [PubMed]

57. Sassi, Y.; Lipskaia, L.; Vandecasteele, G.; Nikolaev, V.O.; Hatem, S.N.; Cohen Aubart, F.; Russel, F.G.; Mougenot, N.; Vrignaud, C.; Lechat, P.; et al. Multidrug resistance-associated protein 4 regulates cAMP-dependent signaling pathways and controls human and rat SMC proliferation. J. Clin. Investig. 2008, 118, 2747-2757. [CrossRef] [PubMed]

58. Schiffmann, S.; Weigert, A.; Mannich, J.; Eberle, M.; Birod, K.; Haussler, A.; Ferreiros, N.; Schreiber, Y.; Kunkel, H.; Grez, M.; et al. PGE2/EP4 signaling in peripheral immune cells promotes development of experimental autoimmune encephalomyelitis. Biochem. Pharmacol. 2014, 87, 625-635. [CrossRef] [PubMed]

59. Linke, B.; Schreiber, Y.; Zhang, D.D.; Pierre, S.; Coste, O.; Henke, M.; Suo, J.; Fuchs, J.; Angioni, C.; Ferreiros-Bouzas, N.; et al. Analysis of sphingolipid and prostaglandin synthesis during zymosan-induced inflammation. Prostaglandins Other Lipid Mediat. 2012, 99, 15-23. [CrossRef] [PubMed]

60. Thomas, D.; Suo, J.; Ulshofer, T.; Jordan, H.; de Bruin, N.; Scholich, K.; Geisslinger, G.; Ferreiros, N. Nano-LC-MS/MS for the quantitation of prostanoids in immune cells. Anal. Bioanal. Chem. 2014, 406, 7103-7116. [CrossRef] [PubMed]

61. Maier, T.J.; Tausch, L.; Hoernig, M.; Coste, O.; Schmidt, R.; Angioni, C.; Metzner, J.; Groesch, S.; Pergola, C.; Steinhilber, D.; et al. Celecoxib inhibits 5-lipoxygenase. Biochem. Pharmacol. 2008, 76, 862-872. [CrossRef] [PubMed]

62. Thoren, S.; Jakobsson, P.J. Coordinate up- and down-regulation of glutathione-dependent prostaglandin E synthase and cyclooxygenase-2 in A549 cells. Inhibition by NS-398 and leukotriene C4. Eur. J. Biochem. 2000, 267, 6428-6434. [CrossRef] [PubMed]

63. Maier, T.J.; Janssen, A.; Schmidt, R.; Geisslinger, G.; Grosch, S. Targeting the $\beta$-catenin/APC pathway: A novel mechanism to explain the cyclooxygenase-2-independent anticarcinogenic effects of celecoxib in human colon carcinoma cells. FASEB J. 2005, 19, 1353-1355. [CrossRef] [PubMed] 
64. Hoffmann, M.; Lopez, J.J.; Pergola, C.; Feisst, C.; Pawelczik, S.; Jakobsson, P.J.; Sorg, B.L.; Glaubitz, C.; Steinhilber, D.; Werz, O. Hyperforin induces $\mathrm{Ca}^{2+}$-independent arachidonic acid release in human platelets by facilitating cytosolic phospholipase A(2) activation through select phospholipid interactions. Biochim. Biophys. Acta 2010, 1801, 462-472. [CrossRef] [PubMed]

65. Chomczynski, P. An reagent for the single-step simultaneous isolation of RNA, DNA and proteins from cell and tissue samples. Biotechniques 1993, 15, 532-537. [PubMed]

(C) 2016 by the authors; licensee MDPI, Basel, Switzerland. This article is an open access article distributed under the terms and conditions of the Creative Commons Attribution (CC-BY) license (http://creativecommons.org/licenses/by/4.0/). 